\title{
Effect of Zein Films on the Growth of Tomato Plants and Evaporative Water
}

\section{Loss}

\author{
Nicholas Parris, ${ }^{1,4}$ David D. Douds, Jr., ${ }^{2}$ Leland C. Dickey, ${ }^{1}$ \\ Robert A. Moreau, ${ }^{1}$ and John Phillips ${ }^{3}$ \\ U.S. Department of Agriculture, Agricultural Research Service, Eastern \\ Regional Research Center, 600 East Mermaid Lane, Wyndmoor, PA 19038
}

Additional index words. nonbiodegradable, black polyethylene sheathing, mulch, photodegradable, corn endosperm, corn gluten meal

\begin{abstract}
Zein is an alcohol-soluble protein isolated from corn. The effect of ground cover films prepared from zein on the growth of tomato plants and corresponding evaporative water loss was investigated in greenhouse experiments. Results indicated that there was a decrease in water loss from the growth media for pots treated with zein films compared to the control (no film). There was an $11 \%$ increase height and $65 \%$ increase in dry weight of the treated plants relative to the control. In a second experiment, tomato plants mulched with zein isolates, low in free fatty acids (LFFA), exhibited an $18 \%$ increase in height and a $28 \%$ increase in dry weight compared to the control. Tomato plants treated with black polyethylene sheathing mulch were the tallest of the plants tested and had the greatest dry weight. Adding corn gluten meal directly to the soil surface resulted in tomato plants that were $26 \%$ taller and $29 \%$ heavier than those grown in untreated soil. Zein isolate films appear to be a viable ground cover replacement for polyethylene sheathing.
\end{abstract}

Nonbiodegradable, polymeric materials presently used as ground cover to control weeds and contain or reduce water evaporation are inexpensive to manufacture but expensive to use because of additional costs in collecting the material after the growing season. In addition, polymer materials, which can cover up to $70 \%$ of a field, increase surface water runoff (Hapeman, 2003). As a result more of the pesticides applied on such fields are found in the runoff. Photodegradable mulches eliminate the need to remove and dispose of plastic at the end of the growing season, but have not been widely adopted because they tend to degrade prematurely (Greer and Dole, 2003). Films prepared from zein, an alcohol soluble protein extracted from the endosperm of the corn kernel, could be an attractive replacement for synthetic ground cover materials. Zein is a hydrophobic protein principally used by the food industry for the preparation of edible films and coatings. Although zein films are considerably more hydrophilic than synthetic films, such as polyethylene and poly (vinylidene chloride), they are still capable of retarding water vapor transmission (Parris et al., 1995).

Commercially, zein is extracted from corn

Received for publication 27 Oct. 2003. Accepted for publication 1 Mar. 2004. We thank John Minutolo and Michael Powell for technical assistance. Mention of trade names or commercial products is solely for the purpose of providing specific information and does not imply recommendation or endorsement by the U.S. Department of Agriculture.

${ }^{1}$ Crop Conversion Science and Engineering Research Unit.

${ }^{2}$ Microbial Biophysics and Residue Chemistry and Core Technologies Research Unit.

${ }^{3}$ Office of Area Director.

${ }^{4}$ To whom correspondence should be addressed.; emai nparris@errc.ars.usda.gov. gluten meal, a byproduct of the wet milling process, using aqueous alcohol (Lawton, 2002). It has been shown that corn gluten meal contains a substance that inhibits root formation in several species, including crabgrass (Christians, 1993). Since commercial zein is extracted from corn gluten meal, films prepared from commercial zein could release these substances, possibly formed by bacterial proteolysis of the film, and inhibit the growth of unwanted grasses. Zein isolated from dry-milled corn contains a mixture of lipids and zein proteins (Dickey et al., 1998). The lipid portion is composed primarily of triacylglycerides and free fatty acids that act as endogenous plasticizers and further enhance the film's flexibility and water vapor barrier properties. It's estimated cost is $\$ 1.00 / \mathrm{lb}$ compared to $\$ 0.50 / \mathrm{lb}$ for bulk polyethylene. Films would be applied in a similar manner to black polyethylene ground cover but the major difference would be that the films would not be picked up at the end of the growing season but allowed to degrade in the field.

In this study we compared the effect of ground cover films prepared from commercial zein and zein isolated from ground corn on the growth of tomato plants and evaporative water loss.

\section{Materials and Methods}

Preparation of Zein films. We obtained corn zein (F-4000) protein from Freeman Industries (Tuckahoe, NY) and poly (ethylene glycol), average MW $\approx 400$ (PEG), from Aldrich Chemical Co. Inc. (Milwaukee, Wis.). Black polyethylene sheathing, 4 mil $(0.1 \mathrm{~mm})$ thick, was obtained locally and food-grade corn gluten from Extremely Green (Abington, Mass.). Corn zein isolates were prepared by batch extraction with $70 \%$ ethanol from dry- milled (preground) yellow dent corn, (Davis Feeds, Perkasie, Pa.) as described by Dickey et al. (1998). Zein isolates, low in free fatty acids (LFFA) were prepared by batch extraction from freshly ground yellow dent corn (Pioneer Hi-Bred International, Inc., Johnston, Iowa). These isolates were LFFA because lipases present in freshly ground corn were not given the opportunity to hydrolyze the triacylglycerides to FFA as in preground corn. Corn zein films were prepared by dissolving a total of $2.0 \mathrm{~g}$ zein $\mathrm{F}-4000+0.5 \mathrm{~g}$ PEG or $2.5 \mathrm{~g}$ zein isolate in 75 $\mathrm{mL} 90 \%$ ethanol. The mixture was heated with stirring at $60^{\circ} \mathrm{C}$ for $10 \mathrm{~min}$. Ethanol solutions were cast in polystyrene Petri dishes, (Thomas Scientific, Swedesboro, N.J.), $150 \mathrm{~mm}$ in diameter. The solutions were dried in a vacuum oven, adjusted to $33.75 \mathrm{kPa}$ at $50{ }^{\circ} \mathrm{C}$.

Fractionation of zein proteins. Zein proteins from ground corn were fractionated and identified on the basis of solubility using a modification of the method described by Esen (1988).Zein isolate (50 g) was stirred with 250 $\mathrm{mL}$ of hexane for $30 \mathrm{~min}$ and the hexane was decanted. The procedure was repeated and the defatted isolate was allowed to dry under nitrogen. The zein isolate was then dissolved in 200 mL 60\% 2-propanol + $0.5 \%$ mecaptoethanol. 2-Propanol $(60 \mathrm{~mL})$ was added to the solution and the $\beta-, \gamma-$, and $\delta$-zeins were precipitated at $4{ }^{\circ} \mathrm{C}$ overnight. The purified zeins were isolated by centrifuging at $12,000 \mathrm{~g}_{\mathrm{n}}$ for 10 min at $4{ }^{\circ} \mathrm{C}$, then lyophilized. The supernatant, containing the $\alpha$-zeins, was diluted with 1600 $\mathrm{mL}$ water and $72 \mathrm{~mL} 3 \mathrm{~m}$ sodium acetate $(\mathrm{pH}$ 6.0). The solution was stored overnight at 4 ${ }^{\circ} \mathrm{C}$ then centrifuged at $5000 \mathrm{~g}_{\mathrm{n}}$, for $10 \mathrm{~min}$ at $4{ }^{\circ} \mathrm{C}$. The supernatant was discarded and the pellet containing the $\alpha$-zein was analyzed by gel electrophoresis.

Lipid analysis. To determine the level of free fatty acids (FFA) in the zein isolate, duplicate 0.5 -g samples of isolate were homogenized with a mixture of $8 \mathrm{~mL}$ chloroform, 16 $\mathrm{mL}$ methanol and $4.3 \mathrm{~mL}$ water. The homogenate was diluted with $8 \mathrm{~mL}$ chloroform and $8 \mathrm{~mL}$ water to form two separate layers. The chloroform layer containing triacylglycerides (TAG) and FFA was separated and quantified by normal phase-HPLC according to the method of Moreau et al. (1996).

Experiment 1: Effect of zein films prepared from corn gluten meal or isolated from dry-

Table 1. Experimental treatments and composition of ground cover. ${ }^{2}$

\begin{tabular}{ll}
\hline Treatment & Composition \\
\hline Experiment 1 & No film \\
Control & $2.0 \mathrm{~g}$ Zein $+0.5 \mathrm{~g} \mathrm{PEG}$ \\
Zein F-4000 & $2.5 \mathrm{~g}$ Zein \\
Zein isolate & \\
Experiment 2 & No film \\
Control & $2.0 \mathrm{~g}$ Zein $+0.5 \mathrm{~g} \mathrm{PEG}$ \\
Zein F-4000 & $2.5 \mathrm{~g}$ Zein \\
Zein isolate & $2.5 \mathrm{~g}$ Zein \\
Zein isolate, LFFA & $4-$ mil black plastic sheeting \\
Polyethylene & 2.0 g granular \\
Corn gluten &
\end{tabular}

${ }^{2}$ See Material and Methods section for the preparation of zein films, polyethylene sheeting and application of corn gluten meal to soil surface.

${ }^{\mathrm{y}} \mathrm{LFFA}=$ low free fatty acids. 
Table 2. Effect of zein films on water loss (g/pot) of potted tomato plants. ${ }^{2}$

\begin{tabular}{|c|c|c|c|c|c|c|c|c|c|}
\hline \multirow[b]{2}{*}{ Treatment } & \multicolumn{9}{|c|}{ Days } \\
\hline & 0 & 7 & 9 & 11 & 14 & 16 & 18 & 21 & $39-40$ \\
\hline Zein F-4000 & $153 \pm 1.6 \mathrm{ab}$ & $154 \pm 3.2 \mathrm{ab}$ & $88 \pm 0.7 a$ & $161 \pm 3.3 \mathrm{ab}$ & $234 \pm 9.5 \mathrm{ab}$ & $132 \pm 3.4 \mathrm{a}$ & $169 \pm 9.0 \mathrm{a}$ & $192 \pm 5.3 \mathrm{a}$ & $122 \pm 7.2 \mathrm{a}$ \\
\hline
\end{tabular}

${ }^{2}$ Means in the same column with no letter in common are significantly different $(p<0.05)$. The estimate of the Bonferroni LSD (least significant difference) is $47.2 ; \mathrm{n}=3$.

${ }^{\mathrm{y}} \mathrm{No}$ film.

Table 3. Lipid extracted from zein isolates.

\begin{tabular}{lcc}
\hline \multirow{2}{*}{ Samples } & \multicolumn{2}{c}{ Lipid wt $(\%)$} \\
\cline { 2 - 3 } $\mathrm{TAG}^{\mathrm{z}}$ & $\mathrm{FFA}^{\mathrm{z}}$ \\
\hline Zein isolate & $5.75 \pm 1.76$ & $35.28 \pm 1.00$ \\
Zein isolate, LFFA & $6.66 \pm 0.01$ & $11.93 \pm 0.15$ \\
\hline${ }^{2}$ TAG = triacyglycerols; FFA = free fatty acids. \\
${ }^{\mathrm{y}} \mathrm{LFFA}=$ low free fatty acids.
\end{tabular}

milled corn on tomato plant growth and evaporative water loss. The zein films were placed directly on the soil surface of 15 -cm plastic pots containing sphagnum-based potting mix (Mycormix; Premier Peat Co., Quebec, Canada). An opening was cut in the center of the films with a scalpel and the tomato seedlings (Lycopersiconesculentum $\mathrm{L}$. 'Brandywine') planted. There were three treatments (films made from commercial zein or zein isolate and controls with no films) each with three replicates (Table 1). Pots were watered by allowing the potted plants to absorb moisture from the bottom to a constant weight. Hoagland's nutrient solution (Hoagland and Arnon, 1938) was applied as a rewatering treatment once every 2 weeks. Pots were reweighed and rewatered every 2 to $3 \mathrm{~d}$ and the water vapor loss determined by difference. After $50 \mathrm{~d}$ of growth in a greenhouse under natural photoperiods the heights of the plants were measured and the number of blossoms counted. The plants were removed from the pots and shoot (stem plus leaves) fresh and dry weights $\left(80^{\circ} \mathrm{C}, 3 \mathrm{~d}\right)$ were determined.

Experiment 2. Effect of FFA concentration of zein films, polyethylene sheeting, and corn gluten meal on plant growth and evaporative water loss. A replication of Expt. 1 was expanded to include several new treatments (Table 1). Black polyethylene sheathing was cut into circles $150 \mathrm{~mm}$ in diameter and placed on the soil and the plants were planted as in experiment 1 . Since there are components of corn gluten present in films prepared from zein F-4000, two grams of corn gluten meal was sprinkled on the soil surface of the pots of another treatment to test the possibility of additional growth benefits. Pots were arranged in a randomized design on a greenhouse bench with 5 pots per treatment. Pots were watered and fertilized, then water loss and plant growth data collected as above.

Statistical analysis. Analysis of variance (ANOVA) was performed on the data to determine the significance of any treatment effects by using SAS statistical software. All treatment comparisons were tested using the Bonferroni LSD mean separation method.

\section{Results and Discussion}

Experiment 1. Commercial zein and zein isolate films acted as water vapor barriers and affected tomato plant growth. Data collected at $21 \mathrm{~d}$ showed that mulch treatment effects had become negligible by that time, indicating that transpiration from the leaves was the primary source of water loss. Therefore, data from then to the end of the experiment are not presented (Table 2). There was evidence of a significant interaction between treatment and time. Examination of the two-way ANOVA yielded evidence that for the first two weeks (except for the $9 \mathrm{~d}$ data) there was a significant difference in water loss between the zein isolate and the control and water loss from the zein F-4000 tended to be intermediate. After 14 d, there was no difference in water loss among the three treatments.

The zein F-4000 film degraded after $4 \mathrm{~d}$. This degradation could not be attributed to the plasticizer since zein isolate films prepared with $20 \%$ PEG did not degrade in a similar fashion (data not shown). Films prepared from blends of zein F-4000 and zein isolate could be used to control film degradation. Comparison of the protein composition of the two types of zeins used to prepare the films indicated the presence of $\beta$-, $\gamma$-, and $\delta$-zeins in the isolate but not in the commercial zein (Parris and Dickey, 2001). Commercial steeping of whole corn in sulfur dioxide, though intended to permit separation of germ and fiber from the endosperm, also facilitates starch and protein separation. Since $\alpha$-zein is the only zein present in commercial zein, it appears that the more water soluble, sulfur rich $\beta-, \gamma-$, and $\delta$-zeins are removed during the steeping process and are not present to form covalently linked disulfide bonds which may be responsible for maintaining the integrity of the film and retarding degradation. Films were prepared containing only $\alpha$-zein or $\beta-, \gamma-$, and $\delta$-zeins by fractionation of the proteins in the zein isolate (Esen, 1988). Films prepared from $\alpha$-zein when used as ground cover began to degrade after $7 \mathrm{~d}$ but films prepared from $\beta$-, $\gamma$-, and $\delta$-zein remained intact for over 2 months (data not shown).

After $50 \mathrm{~d}$ the plants were harvested as described earlier. There was an $11 \%$ increase in height $(44.8 \pm 0.7 \mathrm{~cm}$ vs. $40.3 \pm 1.4 \mathrm{~cm})$ and $65 \%$ increase in dry weight $(5.84 \pm 0.13 \mathrm{~g}$ vs. $3.53 \pm 0.34 \mathrm{~g}$ ) for the plants containing the zein isolate film compared to the control. In addition there was an increase in the number of blossoms $(2.33 \pm 0.33)$ vs. $1.33 \pm 0.33)$ which was significant at $p<0.10$. These results indicated that the zein isolate films enhanced plant growth and warranted further investigation.

Experiment 2. The above experiment was essentially repeated during the next growing season, but for comparative purposes additional treatments were included. Zein isolate, LFFA films were included to determine the effect of FFA on water vapor barrier properties. Zein isolates, LFFA, prepared from corn freshly ground immediately before extraction of the zein proteins contained about one third the amount of FFA found in zein isolate prepared from preground dry-milled corn (Table 3 ). The distribution of FFA in both isolates was linoleic $>$ palmitic $>$ oleic $>$ stearic. Polyethylene films and corn gluten meal were also included in the study primarily to compare water barrier properties and plant growth respectively. Results indicate that there was evidence of a significant interaction between treatment and days of the study (Table 4). Examination of the two-way means yielded evidence that for the first $17 \mathrm{~d}$ (except the 7-d data) there was a significant difference among the six treatments. During that time period, the polyethylene (PE) treatment showed significantly less water loss

Table 4. Effect of various films and corn gluten meal on the water loss (g/pot) of potted tomato plants. ${ }^{2}$

\begin{tabular}{|c|c|c|c|c|c|c|c|c|c|c|}
\hline \multirow[b]{2}{*}{ Treatment } & \multicolumn{10}{|c|}{ Days } \\
\hline & 3 & 7 & 10 & 12 & 14 & 17 & 19 & 21 & 24 & $53-55$ \\
\hline Control $^{y}$ & $102 \pm 1.9 \mathrm{a}$ & $71 \pm 1.4 \mathrm{a}$ & $156 \pm 3.7 \mathrm{a}$ & $145 \pm 1.9 \mathrm{a}$ & $110 \pm 2.5 \mathrm{a}$ & $159 \pm 4.0 \mathrm{a}$ & $75 \pm 4.7 \mathrm{a}$ & $128 \pm 8.0 \mathrm{a}$ & $145 \pm 7.1 \mathrm{a}$ & $108 \pm 5.6 \mathrm{a}$ \\
\hline Zein F-4000 & $75 \pm 2.1 \mathrm{bc}$ & $63 \pm 1.18 \mathrm{a}$ & $145 \pm 3.3 \mathrm{ab}$ & $140 \pm 2.2 \mathrm{ab}$ & $101 \pm 2.7 \mathrm{a}$ & $155 \pm 4.3 \mathrm{ab}$ & $75 \pm 2.4 \mathrm{a}$ & $118 \pm 2.4 \mathrm{a}$ & $146 \pm 5.1 \mathrm{a}$ & $110 \pm 3.3 a$ \\
\hline Zein Isolate & $56 \pm 3.4 \mathrm{bc}$ & $45 \pm 1.0 \mathrm{a}$ & $106 \pm 9.3 b$ & $100 \pm 3.8 \mathrm{bc}$ & $87 \pm 3.3 \mathrm{ab}$ & $132 \pm 3.2 \mathrm{a}$ & $65 \pm 1.6 \mathrm{a}$ & $108 \pm 4.2 \mathrm{ab}$ & $133 \pm 3.0 \mathrm{a}$ & $107 \pm 4.0 \mathrm{a}$ \\
\hline Zein Isolate LFFA ${ }^{x}$ & $64 \pm 1.8 \mathrm{abc}$ & $51 \pm 1.8 \mathrm{a}$ & $104 \pm 5.9 \mathrm{~b}$ & $84 \pm 1.7 \mathrm{~cd}$ & $75 \pm 3.4 \mathrm{ab}$ & $114 \pm 3.8 b$ & $61 \mathrm{a} \pm 2.6$ & $107 \pm 5.5 \mathrm{ab}$ & $137 \pm 8.0 \mathrm{a}$ & $117 \pm 6.3 a$ \\
\hline Polyethylene & $35 \pm 2.1 \mathrm{c}$ & $31 \pm 1.8 \mathrm{a}$ & $59 \pm 1.6 \mathrm{c}$ & $45 \pm 2.7 \mathrm{~d}$ & $45 \pm 1.3 \mathrm{~b}$ & $68 \pm 4.7 \mathrm{c}$ & $39 \pm 3.6 \mathrm{a}$ & $75 \pm 5.8 \mathrm{~b}$ & $104 \pm 13.1 \mathrm{a}$ & $97 \pm 8.4 \mathrm{a}$ \\
\hline Corn Gluten & $97 \pm 2.7 \mathrm{ab}$ & $67 \pm 1.1 \mathrm{a}$ & $154 \pm 3.0 \mathrm{a}$ & $118 \pm 3.0 \mathrm{abc}$ & $99 \pm 1.7 \mathrm{a}$ & $157 \pm 5.9 \mathrm{a}$ & $75 \pm 2.3 \mathrm{a}$ & $112 \pm 6.2 \mathrm{ab}$ & $139 \pm 3.6 \mathrm{a}$ & $135 \pm 4.5 \mathrm{a}$ \\
\hline
\end{tabular}

${ }^{\mathrm{z}} \mathrm{n}=5$. Data collected for days 26, 28, 31, and 33 are not presented since effects of mulch treatment were negligible. Means in the same column with no letter in common are significantly different $(p<0.05)$. The estimate of the Bonferonni LSD (least significant difference) is 43.0 .

'No film.

${ }^{\mathrm{x}} \mathrm{LFFA}=$ low free fatty acids. 
Table 5. Effect of various films and corn gluten meal on plant growth. ${ }^{2}$

\begin{tabular}{|c|c|c|c|c|}
\hline Treatment & $\begin{array}{l}\mathrm{Ht} \\
(\mathrm{cm})\end{array}$ & $\begin{array}{l}\text { Shoot } \\
\text { fresh } \\
\text { wt (g) }\end{array}$ & $\begin{array}{l}\text { Shoot } \\
\text { dry wt } \\
\text { (g) }\end{array}$ & Flowers \\
\hline Control $^{y}$ & $41.5 \pm 2.84 \mathrm{bc}$ & $23.81 \pm 1.32 \mathrm{c}$ & $3.48 \pm 0.26 \mathrm{~b}$ & $1.2 \pm 0.37 \mathrm{a}$ \\
\hline Zein F-4000 & $40.5 \pm 1.18 \mathrm{c}$ & $25.78 \pm 1.59 \mathrm{bc}$ & $3.74 \pm 0.30 \mathrm{ab}$ & $0.4 \pm 0.24 \mathrm{a}$ \\
\hline Zein Isolate & $40.7 \pm 1.76 \mathrm{bc}$ & $28.96 \pm 2.13 b c$ & $4.21 \pm 0.30 \mathrm{ab}$ & $1.2 \pm 0.37 \mathrm{a}$ \\
\hline Zein Isolate, LFFA ${ }^{x}$ & $49.0 \pm 2.32 \mathrm{bc}$ & $32.73 \pm 1.48 \mathrm{ab}$ & $4.46 \pm 0.24 \mathrm{ab}$ & $2.0 \pm 0.71 \mathrm{a}$ \\
\hline Polyethylene & $55.6 \pm 3.91 \mathrm{a}$ & $38.32 \pm 1.50 \mathrm{a}$ & $5.18 \pm 0.53 \mathrm{a}$ & $2.8 \pm 0.92 \mathrm{a}$ \\
\hline Corn Gluten & $52.4 \pm 2.48 \mathrm{ab}$ & $38.28 \pm 1.24 \mathrm{a}$ & $4.47 \pm 0.13 \mathrm{ab}$ & $1.6 \pm 0.24 \mathrm{a}$ \\
\hline
\end{tabular}

${ }^{z_{n}}=5$, numbers in the same column followed by the same letter are not significantly different $(p<0.05)$.

'No film.

${ }^{x}$ LFFA $=$ low free fatty acids.

than the control, while the corn gluten (CG) treatment was not significantly different from the control treatment. For the first $12 \mathrm{~d}$ (again excluding day 7), water loss from the zein isolate treatment was significantly less than the control. After $17 \mathrm{~d}$, there was no difference in water loss among the six treatments, except for PE being significantly lower than the control at day 21 and at day 26 (not shown). Examining the effect of day on each treatment led to maximum water loss at $28 \mathrm{~d}$ (not shown) for each treatment with a decrease in water loss over the last three periods.

The plants were harvested after $55 \mathrm{~d}$. The height response shows that the PE treatment was significantly taller than the control treatment. There was no evidence of any significant height difference between the other treatments and the control treatment (Table 5). The shoot fresh weight response shows significantly higher values for PE, CG and zein isolate, LFFA than the control treatment. There was no evidence of a significant difference in the shoot fresh weight of zein F-4000 or zein isolate and the control treatment. The shoot dry weight response shows significantly higher values for PE than for the control treatment. The plants treated with zein films tended to is the overwhelming contributor to water loss. Subsequent biodegradation of the films would release nutrients to stimulate plant growth and the film need not be disposed of after harvest as with plastic mulches.

\section{Literature Cited}

Christians, N.E. 1993 Preemergence weed control using corn gluten meal. U.S. Patent No. 5,030,268 p. 63-65.

Dickey, L.C., M.F. Dallmer, E.R. Radewonuk, N. Parris, M. Kurantz, and J.C. Craig. 1998. Zein batch extraction from dry-milled corn cereal disintegration by dissolving fluid shear. Cereal Chem. 75:443-448.

have greater dry weights than controls. The number of flowers didn't differ significantly between treatments.

It appears that difference in water loss after treatment of tomato plants with zein films was due to the presence of lipid in the zein isolates since the water loss of plants treated with zein F-4000 was not statistically different from the control.

\section{Conclusions}

Zein isolate films appear to be a viable ground cover replacement for polyethylene sheathing. In contrast to polyethylene sheeting, zein is a potentially inexpensive, degradable product prepared from a renewable resource. Lipids present in the isolate increase water retention in the soil and enhance the growth and dry weight of the plant. Film degradation can be controlled by blending the isolate with commercial zein.

The data presented here suggest a potential valuable contribution of zein films to agriculture in arid climates. The initial deterioration of the films could be timed, through manipulation of the ingredients, to coincide with the closure of the plant canopy when transpiration
Esen,A. 1986. Separation of alcohol-soluble proteins (zeins) from maize into three fractions by differential solubility. Plant Physiol. 80:623-627.

Greer, L. and J.M. Dole. 2003. Aluminum foil, aluminum-painted, plastic, and degradable mulches increase yields and decrease inset-vectored viral diseases of vegetables. HortTechnology 13:276-284.

Hapeman, C. 2003. Plastic mulch. Agr. Res. (July): $14-16$

Hoagland, D.R. and D.I. Arnon. 1938. The waterculture method for growing plants without soil. Univ. Calif. College Agr.-Agr. Expt. Sta. Circ. 347.

Lawton, J.W. 2002. Zein: A history of processing and use. Cereal Chem. 79:1-18.

Moreau, R.A., M.J. Powell, and K.B. Hicks. 1996. Extraction and quantitative analysis of oil from commercial corn fiber. J. Agr. Food Chem. 44:2149-2154.

Parris, N., D.R. Coffin, R.F. Joubran, and H. Pessen. 1995. Composition factors affecting the water vapor permeability and tensile properties of hydrophilic films. J. Agr. Food Chem. 40:1432-1435.

Parris, N. and L.C. Dickey. 2001. Extraction and solubility characteristics of zein proteins from dry-milled corn. J. Agr. Food Chem. 49:3757-3760. 